\title{
KUALITAS PELAYANAN KESEHATAN DI PUSKESMAS PEMBANTU (PUSTU) DESA LEBANG KECAMATAN CENDANA KABUPATEN ENREKANG
}

\author{
Hamdan $^{1}$, Musliha Karim², Samsir Rahim ${ }^{3}$ \\ ${ }^{1)}$ Mahasiswa Jurusan Ilmu Administrasi Negara Unismuh Makassar \\ ${ }^{2)}$ Dosen Jurusan Ilmu Administrasi Negara Unismuh Makassar \\ ${ }^{3)}$ Dosen Jurusan Ilmu Administrasi Negara Unismuh Makassar
}

\begin{abstract}
The objectives of this research were to describe and to explain about the quality of health services at auxiliary community health centers in Lebang village of Cendana subdistrict in Enrekang regency. The research method of this research was quantitative descriptive that used to explain about the quality of auxiliary community health centers. The respondent were 68 people which were chosen by using incidental sampling. There were some steps in procedures of collecting data. They were question, observation, and interview. The collected data were analyzed by using frequency table. The result of the research showed that the quality of health services at auxiliary community health centers was already good and qualified. These results were based on the recapitulations of each indicators as follows tangible, reliability, competence, and responsiveness where all the mean results were in a good and qualified category.
\end{abstract}

Keywords: quality, healthy service

\begin{abstract}
ABSTRAK
Penelitian ini bertujuan untuk menggambarkan dan menjelaskan kualitas pelayanan kesehatan di Puskesmas pembantu (PUSTU) Desa Lebang Kecamatan Cendana Kabupaten Enrekang. Jenis penelitian adalah deskriptif kuantitatif yang menjelaskan mengenai kualitas pelayanan kesehatan di PUSTU. Responden sebanyak 68 orang yang dipilih secara sampling insidental.Teknik pengumpulan data yaitu kuesioner, observasi, dan wawancara. Data tersebut dianalisis secara deskriptif kuantitatif menggunakan tabel frekuensi.Hasil penelitian menunjukkan bahwa kualitas pelayanan kesehatan sudah baik dan berkualitas.Hal ini berdasarkan hasil rekapitulasi dari tiap-tiap indikator yaitu bukti fisik (tangible), keandalan (reliability), kompetensi (competence), dan responsivitas (responsiveness) dengan hasil rata-rata persentase berada pada kategori baik dan berkualitas.
\end{abstract}

Katakunci: kualitas, pelayanan kesehatan. 


\section{PENDAHULUAN}

Pelayanan publik merupakan salah satu bentuk pelayanan yang diberikan oleh pihak pelaksana dalam hal ini adalah pemerintah kepada masyarakat dalam rangka pemenuhan kebutuhan dan pelaksanaan peraturan perundangundangan. Dalam penyelenggaraan pelayanan publik, pemerintah bertanggungjawab untuk memberikan pelayanan yang terbaik dalam rangka menciptakan kepuasan dan kesejahteraan masyarakat. Undang-undang Nomor 25 Tahun 2009 tentang pelayanan publik, menyatkan bahwa pelayanan publik adalah kegiatan atau rangkaian kegiatan dalam rangka pemenuhan kebutuhan pelayanan sesuai dengan peraturan perundang-undangan bagi setiap warga negara dan penduduk atas barang, jasa, dan atau/pelayanan administratif yang disediakan oleh penyelenggara pelayanan publik. Selanjutnya penyelenggara pelayanan publik adalah setiap institusi penyelenggara negara, korporasi, lembaga independen yang dibentuk berdasarkan undang-undang untuk kegiatan pelayanan publik, dan badan hukum lain yang dibentuk semata-mata untuk kegiatan pelayanan publik.

$$
\text { Pelayanan kesehatan }
$$

merupakan salah satu bentuk pelayanan yang wajib untuk ditingkatkan kualitasnya mengingat kesehatan adalah salah satu unsur penting dalam kehidupan manusia. Puskesmas pembantu sebagai salah satu instansi pelayanan kesehatan paling dasar dan mengacu pada standar pelayanan kesehatan yang ada di Puskesmas pada umumnya, memiliki peranan yang penting dalam memelihara kesehatan pasien dalam suatu wilayah tertentu. Begitupun dengan Puskesmas pembantu yang ada di Desa Lebang Kecamatan Cendana Kabupaten Enrekang, memberikan pelayanan yang berkualitas kepada masyarakat merupakan tanggungjawab yang harus dilaksananakan dengan baik. Namun pada kenyataannya masih ada beberapa hal-hal yang membuat masyarakat merasa kuarang puas dengan pelayanan di PUSTU tersebut seperti pelayanan yang kurang tepat waktu, masih minimnya sarana dan 
prasarana kesehatan, serta masih minimnya kompetensi petugas. Hal ini tentu menjadi tanggungjawab oleh pemerintah selaku penyelenggara pelayanan publik khususnya yang menangani bidang kesehatan untuk lebih meningkatkan kualitas layanan kesehatan.

\footnotetext{
Menurut Sedarmayanti (2009) pelayanan berarti melayani suatu jasa yang dibutuhkan oleh masyarakat dalam segala bidang. Kegiatan pelayanan kepada masyarakat merupakan salah satu tugas dan fungsi administrasi negara. Menurut Harahap (2010) pelayanan sebagai suatu kegiatan/keuntungan yang ditawarkan oleh organisasi atau perorangan kepada konsumen yang bersifat tidak berwujud dan tidak dapat dimiliki. Dalam pelayanan yang disebut konsumen adalah masyarakat yang mendapat manfaat dari aktivitas yang dilakukan oleh organisasi atau petugas daro organisasi pelayanan. Sedangkan menurut Lovelock (dalam Waluyo, 2007) menyatakan bahwa pelayanan
}

merupakan respon terhadap kebutuhan manajerial yang hanya akan terpenuhi kalau pengguna jasa itu mendapatkan produk yang mereka inginkan. Menurut Moenir (2015), pelayanan umum adalah kegiatan yang dilakukan oleh seseorang atau sekelompok oramg dengan landasan faktor materil melalui sistem, prosedur, dan metode tertentu dalam rangka usaha memenuhi kepentingan orang lain sesusai dengan haknya.

Menurut Ratminto (2005), menyatakan bahwa pelayanan publik atau pelayanan umum adalah segala bentuk jasa pelayanan, baik dalam bentuk barang publik maupun jasa publik yang pada prinsipnya menjadi tanggungjawab dan dilaksanakan oleh instansi pemerintah di pusat, di daerah, dan di lingkungan badan usaha milik negara (BUMN) atau badan usaha milik daerah (BUMD), dalam rangka pemenuhan kebutuhan masyarakat maupun dalam rangka pelaksanaan ketentuan peraturan perundang-undangan. 
Menurut Morgan dan Murgatroyd (dalam Mukarom, 2015) kualitas adalah bentuk-bentuk istimewa dari suatu produksi atau pelayanan yang mempunyai kemampuan untuk memuaskan kebutuhan masyarakat. Parasuraman (dalam Istianto, 2011) mendefinisikan bahwa kualitas pelayanan publik menunjuk pada seberapa jauh perbedaan antara kenyataan dan harapan para pelanggan atau masyarakat atas layanan yang diterima. Dengan demikian terdapat dua unsur utama dalam kualitas layanan yaitu layanan yang diharapkan (expected service) dengan layanan yang diterima (perceived service). Adapun faktor yang merupakan perwujudan kepuasan pengguna layanan dapat di identifikasi melalui empat dimensi kualitas layanan yaitu (1) aspek tangible yaitu kualitas layanan yang berupa tampilan fisik perkantoran, (2) aspek reliability yaitu kemampuan dalam memberikan pelayanan, (3) aspek assurance yaitu kemampuan untuk memberikan jaminan, (4) aspek empathy yaitu kemampuan memahami kebutuhan pelanggan. Sinambela (2006) menyatakan bahwa kualitas pelayanan publik berhubungan erat dengan pelayanan yang sistematis dan komprehensif yang lebih dikenal dengan konsep pelayanan prima. Dan secara teoritis, tujuan pelayanan publik pada dasarnya adalah memuaskan masyarakat. Untuk mencapai kepuasan itu dituntut kualitas pelayanan prima yang tercermin dari beberapa faktor yaitu (1) transparansi, yakni pelayanan yang bersifat terbuka, mudah dan dapat diakses oleh semua pihak yang membutuhkan dan disediakan secara memadai serta mudah dimengerti, (2) akuntabilitas, yakni pelayanan yang dapat dipertanggungjawabkan sesuai dengan ketentuan peraturan perundang-undangan,

kondisional, yakni pelayanan yang sesuai dengan kondisi dan kemampuan pemberi dan penerima pelayanan dengan tetap berpegang teguh pada prinsip efisiensi dan efektivitas, (4) partisipatif, yakni pelayanan yang dapat mendorong peran serta masyarakat dalam penyelenggaraan pelayanan publik dengan memperhatikan aspirasi, 
kebutuhan, dan harapan masyarakat, (5) kesamaan hak, yaitu pelayanan yang tidak melakukan diskriminasi dilihat dari aspek apapun khususnya suku, ras, agama, golongan, status sosial, dan lain-lain, keseimbangan hak dan kewajiban, yaitu pelayanan yang mempertimbangkan aspek keadilan antara pemberi dan penerima pelayanan.

Zeithmal (dalam Achmad, 2010) menyatakan bahwa terdapat beberapa dimensi yang harus diperhatikan dalam melihat tolak ukur kualitas pelayanan publik. Adapun dimensi-dimensi tersebut yaitu (1) tangible, terdiri dari fasilitas fisik, peralatan, personil, dan komunikasi,(2) reliability, terdiri dari kemampuan unit pelayanan dalam menciptakan pelayanan yang dijanjikan dengan tepat,(3) responsiveness, kemampuan untuk membantu konsumen bertanggungjawab terhadap kualitas layanan yang diberikan, competence, tuntutan dimilikinya pengetahuan dan keterampilan yang baik oleh aparatur negara dalam memberikan pelayanan, (5) courtesy, sikap dan perilaku ramah, bersahabat, tanggap terhadap keinginan konsumen, (6) credibilty, sikap jujur dalam setiap upaya untuk menarik kepercayaan masyarakat, (7) security, jasa pelayanan yang diberikan harus bebas dari berbagai bahaya dan resiko, (8) acces, terdapat kemudahan untuk mengadakan kontak dan pendekatan, (9) communication, kemauan pemberi pelayanan untuk mendengarkan suara, keingintahuan atau aspirasi pelanggan, sekaligus ketersediaan untuk selalu menyampaikan informasi baru kepada masyarakat, (10) understanding the customer, melakukan segala usaha untuk mengetahui kebutuhan pelanggan. Denhart (2013) menyatakan bahwa peningkatan kualitas layanan publik adalah hal yang tidak mudah dan memerlukan waktu karena dibutuhkan kerjasama dai berbagai pihak baik pemerintah, swasta, maupun masyarakat. Meskipun rumit, sudah ada berbagai usaha untuk mendefinisikan kualitas layanan sektor publik. Suatu daftar 
komprehensif yang dikembangkan untuk pemerintah lokal meliputi halhal yaitu (1) kemudahan mengukur seberapa mudah layanan pemerintah terakses dan tersedia bagi warga negara, (2) keamanan mengukur sejauh mana layanan-layanan diberikan dengan cara yang membuat para warga negara merasa aman dan percaya diri ketika menggunakannya, (3) keandalan menilai sejauh mana layanan pemerintah diberikan dengan benar dan tepat waktu, (4) perhatian personal mengukur sejauh mana para karyawan memberikan informasi kepada warga negara dan bekerja dengan mereka, memenuhi kebutuhan mereka, (5) pendekatan pemecahan masalah, mengukur sejauh mana para karyawan memberikan informasi kepada warga negara dan bekerja dengan mereka untuk memenuhi kebutuhankebuthan mereka, (6) kejujuran, mengukur sejauh mana para karyawan percaya bahwa layanan pemerintah diberikan dengan cara yang adil kepada semua orang, (7) tanggungjawab fiskal, mengukur sejauh mana warga negara mempercayai pemerintah lokal memberikan layanan dengan cara menggunakan uang secara bertanggungjawab, (8) pengaruh warga negara, mengukur sejauh mana warga negara merasa bahwa mereka dapat mempengaruhi kualita layanan yang mereka terima dari pemerintah lokal.

\section{METODE PENELITIAN}

Penelitian ini dan dilaksanakan selama bulan April sampai Juni 2016 di puskesmas pembantu (PUSTU) Desa Lebang Kecamatan Cendana Kabupaten Enrekang. Jenis penelitian ini merupakan penelitian deskriptif kuantitatif dengan tipe penelitian adalah survey yaitu mengumpulkan data dan menganalisis suatu peristiwa atau proses tertentu dengan memilih data atau menemukan ruang lingkup tertentu. Populasi dalam penelitian ini sebanyak 214 orang. Teknik penentuan sampel adalah insidental dan jumlah sampel yang dijadikan responden sebanyak 68 orang. Teknik pengumpulan data yaitu (1) kuesioner, (2) wawancara (3) observasi. 


\section{HASIL DAN PEMBAHASAN}

Kabupaten Enrekang dengan ibu kota Enrekang terletak kurang lebih $235 \mathrm{~km}$ sebelah utara Kota Makassar. Keadaan tofografi wilayahnya berupa perbukitan, pegunungan, lembah, dan sungai. Adapun yang menjadi batas-batas wilayah Kabupaten Enrekang yaitu sebelah utara berbatasan dengan Kabupaten Tana Toraja, sebelah selatan berbatasan dengan Kabupaten Luwu, sebelah timur berbatasan dengan Kabupaten Sidrap, sebelah barat berbatasan dengan Kabupaten Pinrang. Visi Kabupaten Enrekang adalah terwujudnya enrekang maju, aman, dan sejahtera menuju daerah agropolitan berwawasan lingkungan. Misi Kabupaten Enrekang adalah (1) meningkatkan kualitas dan ketersediaan infrastruktur pelayanan publik, (2) meningkatkan kualitas sumber daya manusia yang berdaya saing dan aplikasi teknologi.

Desa Lebang merupakan salah satu desa yang berada di Kecamatan Cendana Kabupaten Enrekang. Desa ini terdiri atas tiga dusun yaitu Dusun Lebang, Dusun Garege, dan Dusun Panette. Adapun batas-batas wilayahnya yaitu sebelah utara berbatasan dengan Desa Pinang, sebelah timur berbatasan dengan sungai saddang, sebelah selatan berbatasan dengan Desa Malalin, dan sebelah barat berbatsan dengan Kabupaten Pinrang. Puskesmas pembantu (PUSTU) Desa Lebang merupakan unit pelayanan kesehatan dasar yang berfungsi sebagai penunjang dan membantu memperluas jangkauan Puskesmas induk Kecamatan Cendana dengan memberikan jasa pelayanan kesehatan kepada masyarakat yang membutuhkan baik berupa pelayanan kesehatan promotif, seperti penyuluhan kepada masyarakat tentang pentingnya hidup sehat, maupun pelayanan kesehatan kuratif yaitu penanganan penyakit yang diderita oleh seseorang dengan menyesuaikan kemampuan yang dimiliki oleh para petugas, serta kelengkapan sarana dan prasarana yang ada..

Secara rinci di jelaskan mengenai tugas dan fungsi PUSTU yaitu (1) membantu melakukan kegiatan-kegiatan yang dilakukan unit pelaksana dinas (UPTD) dalam 
ruang lingkup wilayan yang lebih kecil, (2) melaksanakan pelayanan kesehatan dasar kepada masyarakat melalui pelayanan kesehatan ibu, anak, keluarga berencana, perbaikan gizi, imunisasi, dan pengobatan sederhana, (3) melaksanakan penyuluhan dan pembinaan peran serta masyarakat dalam wilayah kerja tertentu yang ditetapkan UPTD, (4) melaksanakan tugas-tugas lain yang diberikan oleh kepala UPTD sesuai dengan tugas dan fungsinya.

Karena merupakan sebuah instansi kecil, maka susunan kepengurusan PUSTU Desa Lebang Kecamatan Cendana tersebut berbentuk sederhana dengan jumlah petugas yang terbatas yakni hanya berjumlah tiga orang. Dua orang bidan sebagai anggota dan seorang bidan lainnya, selain memberikan pelayanan kesehatan kepada masyarakat, juga bertindak sebagai penanggungjawab atau kepala PUSTU. Dan kepala PUSTU tersebut bertanggungjawab kepada kepala puskesmas Kecamatan Cendana dengan melakukan kegiatan seperti melaporkan segala hal-hal atau aktivitas yng berkaitan dengan pelaksanaan pelayanan kesehatan setiap akhir bula, serta mengajukan surat permintaan fasilitas kesehatan seperti obat-obatan dan alat-alat kesehatan apabila ketersediaan barang tersebut dianggap mulai kurang. Puskesmas pembantu dalam melaksanakan fungsinya untuk memberikan pelayanan kepada masyarakat tidak terlepas dari tujuan yang ingin dicapai. Hal tersebut dituangkan dalam visi yang merupakan tujuan jangka panjang yang ingin dicapai, dan juga misi yaitu langkah-langkah yang dilakukan untuk mencapai tujuan jangka panjang tersebut. Adapun visi yaitu terwujudnya PUSTU Desa Lebang sebagai pusat kesehatan yang bermutu dan merata serta terjangkau dengan masyarakat yang senantiasa berperilaku hidup bersih dan sehat dalam lingkungan yang bersih dan sehat menuju Desa Lebang yang sehat. Misi yaitu

menyelenggarakan pelayanan kesehatan secara bermutu serta terjangkau oleh masyarakat, (2) meningkatkan pembinaan peran serta masyarakat dalam bidang kesehatan sehingga masyarakat bisa mandiri, 
(3) membudayakan perilaku hidup bersih dan sehat melalui gerakan hidup bersih dan sehat (GBHS) dan desa siaga/desa sehat, (4) mengembangkan sarana dan mutu pelayanan sesuai kebutuhan masyarakat.

Kualitas pelayanan kesehatan di Puskesmas Pembantu (PUSTU) Desa Lebang Kecamatan Cendana Kabupaten Enrekang, menunjuk pada seberapa jauh perbedaan antara kenyataan dan harapan para penerima pelayanan dalam hal ini adalah masyarakat atas layanan yang diterima dari para petugas yang ada di PUSTU tersebut. Apabila pelayanan kesehatan yang diterima oleh masyarakat khususnya para pasien sudah sesuai atau bahkan melebihi daripada harapan mereka, maka dapat dikatakan bahwa pelayanan kesehatan di instansi tersebut sudah baik. Begitupun sebaliknya, jika pelayanan kesehatan yang diterima oleh para masyarakat kurang sesuai atau bahkan jauh dari hari harapan mereka, maka pelayanan tersebut dikatakan tidak baik atau kurang berkualitas.
PUSTU sebagai unit pelaksana teknis pelayanan kesehatan tingkat dasar diharapkan memberikan pelayanan yang sebaikbaiknya kepada masyarakat demi terciptanya kepuasan masyarakat akan pelayanan kesehatan.

Adapun yang menjadi indikator penilaian dalam pelayanan kesehatan di Puskesmas pembantu (PUSTU) Desa Lebang Kecamatan Cendana Kabupaten Enrekang adalah faktor bukti fisik (tangible) yang terdiri atas kondisi ruang tunggu, kondisi ruang pemeriksaan, kondisi ruang inap, dan kelengkapan fasilitas kesehatan, faktor keandalan (reliability) yang terdiri atas kemampuan yang dimiliki oleh para petugas dan ketepatan waktu dalam pemberian pelayanan kepada masyarakat, faktor kompetensi (competence) terdiri atas pengetahuan yakni mengenai tingkat pendidikan dan juga keterampilan yang dimiliki oleh para petugas, dan faktor responsivitas (responsiveness) terdiri atas daya tanggap para petugas dalam pemberian pelayanan kepada masyarakat, dan kemauan 
bertanggungjawab oleh para petugas mengenai tugas yang dilaksanakan.

\section{Bukti fisik (tangible)} merupakan tampilan fisik serta fasilitas fisik berupa sarana dan prasarana yang berpengaruh dalam menunjang terciptanya pelayanan yang baik kepada masyarakat. Adapun yang menjadi indikator penilaian yaitu (1) kondisi ruang tunggu, merupakan tempat pasien menuggu giliran untuk diperiksa oleh petugas kesehatan jika terjadi antrian dan juga ketika pasien tidak dalam keadaan darurat. Kondisi ruang utnggu yang baik, nyaman dan bersih turut menjadi penilaian oleh masyarakat. (2) kondisi ruang pemeriksaan yang merupakan salah satu tempat pasien untuk melakukan konsultasi awal mengenai kesehatan dengan petugas yang ada, (3) kondisi ruang inap merupakan tempat perawatan khusus untuk pasien yang masih bisa ditangani oleh petugas namun pasien tersebut harus menginap, (4) kelengkapan fasilitas berupa sarana dan prasarana kesehatan yang digunakan oleh para petugas dalam memberikan pelayanan kesehatan kepada masyarakat.

Tabel. 1

Rekapitulasi tanggapan responden mengenai bukti fisik (tangible) dalam pelayanan kesehatan

\begin{tabular}{|c|c|c|c|}
\hline No & Pernyataan & Skor & Rata-rata persentase (\%) \\
\hline 1 & Kondisi ruang tunggu & 3,19 & $79 \%$ \\
\hline 2 & Kondisi ruang pemeriksaan & 3,47 & $86 \%$ \\
\hline 3 & Kondisi ruang inap & 3,07 & $76 \%$ \\
\hline 4 & Kelengkapan fasilitas & 2,76 & $69 \%$ \\
\hline \multicolumn{2}{|c|}{ Rata-rata skor dan rata-rata persentase } & 3,12 & $77,5 \%$ \\
\hline
\end{tabular}

Sumber: hasil olah data

Data pada tabel diatas menunjukkan hasi rekapitulasi penilaian yang dilakukan oleh para responden yang berjumlah 68 orang mengenai bukti fisik (tangible) dalam pelayanan kesehatan di PUSTU Desa Lebang Kecamatan
Cendana Kabupaten Enrekang. Berdasarkan data tersebut dapat diketahui bahwa kondisi ruang tunggu yang ada dapat dikategorikan baik dengan rata-rata skor dan persentase 3,19 (79\%). Selanjutnya mengenai kondisi ruang pemeriksaan 
dengan nilai rata-rata skor dan ratarata persentase $3,47(86 \%)$ berada pada kategori sangat baik dan diperkuat dengan pernyataan Selanjutnya mengenai kondisi ruang inap dengan nilai rata-rata skor dan rata-rata persentase $3,07 \quad(76 \%)$ berada pada kategori baik dan diperkuat dengan pernyataan, dan kelengkapan fasilitas dengan nilai rata-rata skor dan rata-rata persentase 2,76 (69\%) berada pada kategori baik. Dengan demikian dapat disimpulkan bahwa keadaan bukti fisik (tangible)dikategorikan baik dan berkualitas dengan nilai rata-rata skor dan rata-rata persentase 3,12 $(77,5 \%)$.

Keandalan (reliability) merupakan kemampuan sumber daya manusia dalam menjalankan tugasnya dengan baik. Dalam hal ini adalah kemampuan yang dimiliki oleh para petugas PUSTU dalam memberikan pelayanan kesehatan kepada masyarakat. Baik itu kemampuan dalam menangani pasien seperti mampu dalam menangani penyakit yang diderita oleh pasien maupun mendeteksi atau mendiagnosa gejala-gejala penyakit yang diderita oleh pasien sehingga bisa segera ditentukan apakah pasien tersebut ditangani atau dirujuk, maupun ketepatan waktu yakni adanya kepastian mengenai waktu pelaksanaan pelayanan seperti membuka jam pelayanan tepat waktu. Dengan adanya kepastian mengenai waktu pelaksanaan pelayanan, masyarakat tidak harus menunggu dan bertanya-tanya mengenai waktu sebuah intansi dalam memberikan pelayanan. Begitupun dengan puskesmas pembantu, membuka jam pelayanan yang tepat waktu membuat masyarakat dalam hal ini adalah pasien yang datang bisa langsung dilayani karena sudah ada petugas yang sebelumnya telah siap melayanani. Faktor ini sangat berpengaruh terhadap kualitas layanan yang diterima oleh para masyarakat khususnya yang menggunakan jasa layanan kesehatan tersebut. 
Tabel. 2

Rekapitulasi tanggapan responden tentang keandalan (reliability) dalam pelayanan kesehatan

\begin{tabular}{|c|c|c|c|}
\hline No & Pernyataan & Skor & Rata-rata persentase (\%) \\
\hline 1 & Kemampuan petugas & 3,35 & $83 \%$ \\
\hline 2 & Ketepatan waktu & 3,07 & $76 \%$ \\
\hline \multicolumn{2}{|c|}{ Rata-rata skor dan rata-rata persentase } & 3,20 & $79 \%$ \\
\hline
\end{tabular}

Sumber: Hasil olah data

Tabel di atas merupakan hasil rekapitulasi dari dua indikator keandalan (reliability) yang menjadi penilaian oleh para responden yaitu kemampuan petugas dalam memberikan pelayanan dengan nilai rata-rata skor dan rata-rata persentase $3,35(83 \%)$ berada pada kategori sangat baik. dan ketepatan waktu dalam pemberian pelayanan dengan rata-rata skor dan rata-rata persentase 3,07 (76\%) berada pada kategori baik. Berdasarkan hasil olah data, diperoleh hasil nilai rata-rata 3,20 dengan nilai persentase $79 \%$. Sehingga dapat disimpulkan bahwa keandalan (reliability) dalam pelayanan kesehatan di PUSTU

tersebut dikategorikan baik dan berkualitas.

Kompetensi (competence) merupakan suatu hal yang sangat penting dalam menunjang pemberian pelayanan yang baik dan berkualitas kepada masyarakat. Begitupun dengan pelayanan kesehatan di PUSTU, kompetensi yang memadai harus dimiliki oleh para petugas demi terwujudnya pelayanan kesehatan yang memuaskan masyarakat. indikator penilaian adalah pengetahuan dan juga keterampilan, yang sangat penting dalam pemberian pelayanan kesehatan untuk menghindari kesalahan dalam penanganan pasien.

Tabel. 3

Rekapitulasi tanggapan responden mengenai kompetensi (competence) petugas dalam pemberian pelayanan kesehatan

\begin{tabular}{|c|c|c|c|}
\hline No & Pernyataan & Skor & Rata-rata persentase (\%) \\
\hline 1 & Pengetahuan petugas & 3,13 & $78 \%$ \\
\hline 2 & Keterampilan petugas & 3,44 & $86 \%$ \\
\hline \multicolumn{2}{|c|}{ Rata-rata skor dan rata-rata persentase } & 3,28 & $82 \%$ \\
\hline
\end{tabular}

Sumber: Hasil olah data 
Data pada tabel di atas merupakan rekapitulasi dari dua indikator kompetensi (competence) yang menjadi penilaian oleh para responden yang berjumlah 68 orang, yakni pengetahuan yang dimiliki oleh para petugas diperoleh nilai rata-rata skor dan persentase 3,13 (78\%) dan dapat dikategorikan baik serta keterampilan petugas dalam melaksanakan pelayanan kesehatan kepada masyarakat, dengan nilai rata-rata skor dan persentase 3,44 (86\%) berada pada kategori sangat baik. Berdasarkan hasil olah data, diperoleh nilai rata-rata skor 3,28 dan rata-rata persentase yaitu $82 \%$. Dengan demikian dapat disimpulkan bahwa kompetensi yang dimiliki oleh para petugas sudah baik dan sangat baik dan berkualitas.

$$
\text { Indikator yang menjadi }
$$

penilaian selanjutnya adalah responsivitas (responsiveness) merupakan salah satu faktor yang berkaitan dengan daya tanggap, yakni kesigapan serta kecepatan para petugas dalam memberikan respon serta penanganan kepada masyarakat dalam hal ini adalah pasien tanpa harus menunggu terlalu lama dan bisa langsung diberikan pelayanan sesuai dengan keperluan dan keluhan mereka. Selanjutnya adalah mengenai kemauan para petugas untuk bertanggungjawab terhadap masyarakat jika terjadi suatu kesalahan mengenai tugas yang dilaksanakan yang berkaitan dengan pelaksanaan pelayanan kesehatan. Pertanggungjawaban mengenai kualitas pelayanan yang diberikan sangat berpengaruh terhadap kepuasan masyarakat sebagai penerima layanan kesehatan.

Tabel. 4

Rekapitulasi tanggapan responden mengenai responsivitas (responsiveness) dalam pelayanan kesehatan

\begin{tabular}{|c|c|c|c|}
\hline No & Pernyataan & Skor & Rata-rata persentase (\%) \\
\hline 1 & Kemauan bertanggungjawab & 3,58 & $89 \%$ \\
\hline 2 & Daya tanggap & 3,52 & $88 \%$ \\
\hline \multicolumn{2}{|c|}{ Rata-rata skor dan rata-rata persentase } & 3,55 & $88,5 \%$ \\
\hline
\end{tabular}

Sumber: Hasil olah data 
Berdasarkan tabel 4 tersebut diatas, dapat diketahui bahwa kemauan untuk bertanggungjawab oleh para petugas PUSTU dalam melaksanakan tugasnya sebagai pelaksana pelayanan kesehatan dasar kepada masyarakat dapat dikatakan sudah sangat baik. Hal ini berdasarkan rekapitulasi penilaian yang dilakukan oleh responden yang berjumlah 68 orang dan diperoleh nilai rata-rata skor dan rata dan persentase yaitu 3,58 (89\%). Begitupun dengan hasil penilaian oleh para responden terhadap daya tanggap para petugas dalam memberi pelayanan kesehatan kepada masyarakat yang berada pada kategori sangat baik dengan nilai rata-rata skor dan rata-rata persentase yaitu 3,52 (88\%). Sehingga dapat disimpulkan bahwa faktor responsivitas (responsiviness) dalam pelayanan kesehatan di PUSTU sangat baik dan berkualitas dengan nilai rata-rata skor 3,55 dan rata-rata persentase $88,5 \%$.

Tabel 5

Rekapitulasi rata-rata skor dan rata-rata persentase indikator kualitas pelayanan kesehatan

\begin{tabular}{|c|l|c|c|c|}
\hline No & Indikator & Skor & Persentase & kategori \\
\hline 1 & Bukti fisik & 3,12 & $77,5 \%$ & Berkualitas \\
\hline 2 & Keandalan & 3,20 & $79 \%$ & berkualitas \\
\hline 3 & Kompetensi & 3,28 & $82 \%$ & Sangat berkualitas \\
\hline 4 & Responsivitas & 3,55 & $88,5 \%$ & Sangat berkualitas \\
\hline
\end{tabular}

Sumber: Hasil olah data

Data pada tabel tersebut merupakan hasil rekapitulasi nilai rata-rata skor dan rata-rata persentase dari ke empat indikator kualitas pelayanan kesehatan yang menjadi penilaian oleh para responden yang berjumlah 68 orang, di PUSTU Desa Lebang Kecamatan Cendana Kabupaten Enrekang. Bukti fisik (tangible) berada pada kategori berkualitas dengan rata-rata skor dan persentase
3,12 (77,5\%), keandalan (reliability) dengan nilai rata-rat skor dan persentase 3,20 (79\%) berada pada kategori berkualitas. Adapun indikator kompetensi (competence) dikategorikan sangat berkualitas dengan rata-rata skor dan persentase 3,28 (82\%). Dan responsivitas (responsiveness) dengan nilai ratarata skor dan persentase 3,55 
$(88,5 \%)$ berada pada kategori sangat berkualitas pula.

\section{KESIMPULAN}

Berdasarkan hasil penelitian, maka dapat disimpulkan bahwa pelayanan kesehatan di Puskesmas pembantu (PUSTU) Desa Lebang Kecamatan Cendana Kabupaten Enrekang sudah baik dan berkualitas. Hal ini berdasarkan hasil akumulasi data secara umum yang diberikan oleh para responden yang berjumlah 68 orang mengenai indikator kualitas pelayanan yaitu bukti fisik (tangible) dengan indikator penilaian yaitu kondisi ruang tunggu, kondisi ruang pemeriksaan, kondisi ruang inap, dan kelengkapan fasilitas, dikategorikan baik dan kerkualitas. Keandalan (reliability) dengan indikator penilaian yaitu kemampuan petugas dan ketepatan waktu dalam memberi pelayanan berada pada kategori baik dan berkualitas. Kompetensi (competence) dengan indikator penilaian yaitu pengetahuan dan keterampilan yang dimiliki oleh para petugas dapat dikategorikan sangat berkualitas. Dan responsivitas (responsiveness) dengan indikator penilaian adalah kemauan bertanggungjawab dan daya tanggap petugas dikategorikan baik dan berkualitas.

\section{DAFTAR PUSTAKA}

Achmad, Mansyur, 2010. Teori-teori Mutakhir Administrasi Publik. Yogyakarta: Rangkang Education.

Denhart V. Janet dan Robert B. Denhart. 2013. Pelayanan Publik Baru : Dari Manajemen Steering ke Serving. Sidorejo : Kreasi Wacana.

Harahap, Tri Rustiana, 2010. Studi Tentang Kualitas Pelayanan Publik (Studi Kasus KTO di Kota Bekasi). Yogyakarta: MAP-UGM.

Istianto, Bambang, 2011. Manajemen Pemerintahan dalam Perspektif Pelayanan. Jakarta: Mitra Wacana Media.

Moenir, 2015. Manajemen Pelayanan Umum di Indonesia. Jakarta: Bumi Aksara.

Mukarom, Zaenal, 2015. Manajemen Pelayanan Publik. Bandung: CV Pustaka Setia.

Ratminto dan Atik Septi Winarsih, 2005. Manajemen Pelayanan :pengembangan model, konseptual, penerapan citizen's charter dan standar pelayanan minimal, Yogyakarta: Pustaka Pelajar. 
Sedarmayanti, 2009. Reformasi Administrasi Publik, Reformasi Birokrasi, dan kepemimpinan Masa Depan (Mewujudkan Pelayanan Prima dan Kepemerintahan yang baik). Bandung: PT Refika Aditama.

Sinambela, dkk. 2006. Reformasi Pelayanan Publik teori, kebijakan, dan implementasi. Jakarta: PT Bumi Aksara.

Waluyo, 2007. ManajemenPublik :Konsep, Aplikasi dan Implementasinya Dalam Pelaksanaan Otonomi Daerah). Bandung : Mand 